\title{
Study on PLC Teaching Reform Oriented by Cultivation of Practice Abilities \& Innovative Awareness
}

\author{
Zhiliang Kang ${ }^{1, a}$ and Peng Huang ${ }^{1, b^{*}}$ \\ ${ }^{1}$ College of Mechanical and Electronic Engineering, Sichuan Agricultural University, Ya'an, 625014, \\ China \\ aZZhiliangkang96@163.com, hhpsjdyd@189.cn \\ *The corresponding author
}

Keywords: Teaching reform, PLC, Practice ability, Innovative awareness

\begin{abstract}
In-depth analysis and study were carried out to PLC (programmable logic controller) teaching reform and a great deal of teaching reform practices were also performed in the principle of "research as reforming and practicing". Promoting the teaching reform of "three modules" under the guiding thought of "one basis, two cores", i.e. the three modules of teaching content, teaching methodology and teaching staff are reformed on the basis of cultivating the students' basic PLC application abilities regarding cultivation of practice ability and innovative awareness as cores. Inspiring the students' passion for study and constantly improving teaching quality.
\end{abstract}

\section{Introduction}

Sichuan Agricultural University, as a provincial key university, is the sole regional institution of higher learning listed in "211 Project" (the project of constructing 100 key universities in the 21 st century) of Sichuan Province. Since establishment of the major of agricultural electrification and automation in 1994, we have been carrying out long-term and arduous study and exploration on how to construct efficient and practical courses teaching system in the principle of establishing efficient and suitable professional knowledge system and improving the students' comprehensive quality for the purpose of cultivating inter-disciplinary engineering applied technical talents with sound theoretical basis, abundant practice abilities and strong innovative sense in the field of agricultural electrification and automation. As a compulsory course, PLC naturally becomes the preferred course for teaching reform [1-2]. This course has features of strong practicableness, closely related to production and wide scope of knowledge is utilized. Therefore, implementation of teaching reform is greatly significant to cultivate the students into applied and innovative talents that adapt to the development trend of science and technology [3].

\section{Guiding Thought of PLC Course Reform}

The teaching reform of the PLC course is guided by the thought of "one basis, two cores", i.e. both emphasizing on the students' basic abilities of PLC application and focusing on cultivating the students' practice abilities and innovation awareness. PLC is a course with strong nature of application, thus cultivating the practice abilities of the students is undoubtedly a core of course reform. On the basis of completing experiments, the PLC course should focus on strengthening the training link, emphasize on cultivation of practice abilities in order to meet requirements of cultivating high level engineering applied technical talents of agricultural electrification and automation. "Innovation, as the soul for a nation to make progress, constantly propels the country to be prosperous and success, and a nation without innovative ability can hardly stand firm among the nations of the world" [4-5]. Having an important position in national construction and innovation system, institutions of higher learning are main driving force for construction of national innovation system and sustain great responsibilities for cultivating innovative talents [6]. Therefore, cultivating the innovative awareness of the students is another core of teaching reform of PLC course. 


\section{Main Content of PLC Course Reform}

Following the guiding thought of "one basis and two cores", it will focus on reforming and exploration on "three modules", i.e. reform of teaching content, teaching methods and construction of teaching staff. Upon analyzing cultivation objectives of agricultural electrification and automation major, investigating employment conditions of the students in this major in previous years and staffing requirements of employing units, we reorganized the teaching content of this course, modularized and systematized the teaching content. In order to meet requirements of cultivation of practice abilities and innovative awareness, previous teaching methodology and measures were reformed and innovated in PLC teaching practice. The traditional teaching course was gradually changed into heuristic, discussion-based and research-oriented teaching. This made the students become greatly passionate for study and more initiative. Teaching staff is the soul of teaching reform, so only when they keep on exploring and innovating can the course teaching reform be continuously deepened and perfected. The most important point of construction of teaching staff is establishing "double-teaching mode" teaching team, i.e. teachers of major courses can both impart theoretical knowledge and can guide professional practices, thus achieving organic integration of theoretical and practice teaching.

\section{Reform and Exploration of Teaching Content}

Theoretical Teaching. As shown in Table 1, the content of PLC theoretical teaching comprises of five modules that are PLC hardware and operating principles, PLC instruction systems, PLC programming and application, programming software and dynamic design as well as network communication. Modularized teaching is adopted in theoretical teaching. Being both independent from one another and interrelated, these five modules form integral knowledge system of the PLC course. Focusing on teaching operating principles of PLC and analysis and design of control systems formed by PLC; emphasizing application of network technology of PLC control system; and the difficulty lies in design and development of host computer monitoring software in control system. In adjustment of teaching content, it emphasized on the systematic property and integrity of automation discipline, paid attention to the property of practical engineering application and strengthened the link of practice.

Table 1 Content of PLC theoretical teaching

\begin{tabular}{|c|c|c|}
\hline $\begin{array}{c}\text { Module of theoretical } \\
\text { teaching. }\end{array}$ & Main content & $\begin{array}{c}\text { Arrangement of } \\
\text { teaching hours }\end{array}$ \\
\hline $\begin{array}{c}\text { PLC hardware and } \\
\text { operating principles }\end{array}$ & $\begin{array}{c}\text { Overview, features, hardware structure and } \\
\text { operating principles of SIMENS S7-200/300/400 }\end{array}$ & 8 credit hours \\
\hline $\begin{array}{c}\text { Instruction system of } \\
\text { PLC }\end{array}$ & $\begin{array}{c}\text { SIMENS S7-200 programming language, address } \\
\text { assignment, logical operation, counter, timer and } \\
\text { function instructions. }\end{array}$ & 16 credit hours \\
\hline $\begin{array}{c}\text { PLC programming and } \\
\text { application }\end{array}$ & $\begin{array}{c}\text { PLC programming method and application of PLC } \\
\text { in analog quantity closed loop control. }\end{array}$ & 8 credit hours \\
\hline $\begin{array}{c}\text { Programming software } \\
\text { and dynamic design }\end{array}$ & $\begin{array}{c}\text { STEP 7-Micro/WIN programming software and } \\
\text { WINCC flexible dynamic design. }\end{array}$ & 8 credit hours \\
\hline Network communication & $\begin{array}{c}\text { PLC and networking control of PLC, computer and } \\
\text { transducer. }\end{array}$ & 8 credit hours \\
\hline
\end{tabular}

The practice link of PLC mainly comprises five parts that are experimental teaching, course reports or theses, course design, practices outside school, skill contest or scientific research activities. See Table 2 for details. In addition to these specified practice teaching links, excellent students can also form teams to participate in all kinds of contents and scientific research projects for improving practice abilities and cultivating innovative awareness [7-8]. 
Table 2 Main content of practice teaching

\begin{tabular}{|c|c|c|}
\hline $\begin{array}{c}\text { The module of } \\
\text { practice teaching }\end{array}$ & Main content & $\begin{array}{c}\text { Arrangement of } \\
\text { teaching hours }\end{array}$ \\
\hline $\begin{array}{c}\text { Experimental } \\
\text { teaching }\end{array}$ & $\begin{array}{c}\text { Basic instruction experiments; applied experiments; } \\
\text { comprehensive and design type experiments; }\end{array}$ & 12 credit hours \\
\hline $\begin{array}{c}\text { Course reports or } \\
\text { theses }\end{array}$ & $\begin{array}{c}\text { Teachers assign course reports or small theses, and the } \\
\text { students consults literatures and design experiments; }\end{array}$ & 4 credit hours \\
\hline Course design & $\begin{array}{c}\text { Voluntarily form team and choose subjects, submit } \\
\text { course design reports and demonstrate control systems; }\end{array}$ & 1 week \\
\hline $\begin{array}{c}\text { Practice outside } \\
\text { school }\end{array}$ & $\begin{array}{c}\text { Visit or practice in practice base outside school, } \\
\text { understand application, operation and maintenance } \\
\text { conditions of PLC in plant and strengthen the } \\
\text { understanding of industrial application of PLC; }\end{array}$ & $\begin{array}{c}\text { End of semester and } \\
\text { summer vacation }\end{array}$ \\
\hline $\begin{array}{c}\text { Contents and } \\
\text { scientific research } \\
\text { activities }\end{array}$ & $\begin{array}{c}\text { Participate in all kinds of contest and scientific research } \\
\text { activities, strengthen innovative awareness and promote } \\
\text { practice abilities; }\end{array}$ & Extracurricular time \\
\hline
\end{tabular}

With regard of organizational form, the experimental teaching focuses on the students and supported by teachers; with regard of content, it focuses on applied, comprehensive, design-based and innovative experiments and supported by basic and confirmatory experiments. PLC involves a great many of experiments, and those experiments that could not be finished within the stipulated credit hours can be done by the students in open lab during extracurricular time. Meanwhile, the students can make use of existing conditions of the lab to independently design experiment and improve PLC application skills. Content of PLC experimental teaching is shown as Table 3;

Table 3 Content of PLC experimental teaching

\begin{tabular}{|c|c|c|}
\hline Experiment & Main content & $\begin{array}{c}\text { Teaching } \\
\text { hours }\end{array}$ \\
\hline $\begin{array}{c}\text { Function and application } \\
\text { experiment of bit logic instructions }\end{array}$ & $\begin{array}{c}\text { Trolley automatically travels back and forth, } \\
\text { three-location control of corridor lamp, motor } \\
\text { forward and backward rotates }\end{array}$ & 2 credit hours \\
\hline Timing/counting experiment & $\begin{array}{c}\text { Signal light delayed on/off control, button } \\
\text { counting }\end{array}$ & 2 credit hours \\
\hline Sequence control & Traffic light control, music fountain control & 2 credit hours \\
\hline $\begin{array}{c}\text { Displacement instructions and } \\
\text { circulation instructions }\end{array}$ & Day tower light control & 2 credit hours \\
\hline Dynamic software design & Multiple liquid mixing control & 2 credit hours \\
\hline Analog quantity closed loop control & Temperature PID control & 2 credit hours \\
\hline
\end{tabular}

Course design is arranged in the second semester after this course is learned. The course design offers 30 design subjects for the students to choose. The students voluntarily form teams ( 3 members per team), and the lab opens all day long. After a subject is selected, each team cooperatively finishes the course design. While submitting course design report after design is finished, each team demonstrates their own design projects. The control objects with lower cost or the PLC control systems with models in lab shall be demonstrated with material objects or models. The control systems without model or material objects shall be demonstrated with models simulated by PLC driven configuration frames.

In addition to practice sites provided by PLC special lab, we also actively cooperate with enterprises in order to meet the higher requirements to students' operation abilities and practice abilities under the new trend. After PLC course is completed, the teachers arrange students to visit and 
study at the practice bases. Engineering technicians of the enterprises will instruct the application of PLC in plants, meanwhile the students can also exchange with workers and technical staffs in workshop for understanding practical operation and maintenance of PLC.

Both the university and school pay great attention to cultivation of the students' scientific research abilities and innovative awareness. Since 2009, the school launched "scientific research interest cultivation plan" and let excellent students participate in teachers' scientific research projects and finish some sub-projects, and the funds are sponsored by both school and teachers. The students are also organized to participate in all kinds of contest and sign up for all kinds of items such as the challenge cup, electronic design contents, etc. Since the "Innovative Experimental Projects for College Students" was launched by the Ministry of Education in 2008, the students major in agricultural electrification and automation signed up for 30 innovative experimental items at university level under guidance of teachers during 2008-2016. These scientific research activities and skill contests greatly exercised students' practice abilities and inspired their innovative awareness.

\section{Reform and Exploration of Teaching Methodology}

Heuristic, discussion-based and research-oriented teaching methodology is adopted for arousing the students' enthusiasm of study, and modernized teaching measures are utilized for improving teaching quality and efficiency. The project experience and scientific research achievements are introduced into the teaching process for inspiring the students' innovative awareness, cultivating research abilities, and course reports are also arranged for guiding the students to carry out literature retrieval, independently designing experiments and improving the students' practice abilities and innovative awareness.

Teaching Atmosphere. In the process of teaching, the teachers always regard the students as the main body and enable them enjoy adequate "participation right" and "selection right". It shall both make the students correctly learn knowledge and cultivate their innovative spirit and abilities. Therefore, we offered discussion-based and research-oriented class teaching. Let the students study and research together with the teachers, raise questions and discussion together so as to arouse their curiosity and interest and cultivate their innovative awareness.

Real Scene Teaching. Real scene teaching that the teaching content is visualized and materialized makes teaching be lively and interesting, thus arousing the students' interest and innovative awareness. For example, when PLC operating principles are taught, they are associated with the operating modes of computer control, SCM control and relay control systems; when PLC instructions are taught, they are associated with functions of electric control relay. In this way, while understanding the content of this course, the students are able to find out the differences and relationship between this course and other courses and comprehensively understand all course systems [9-10].

Course Reports. During certain teaching interval, reading reports are assigned to the students and the content of reading reports depends on the content of teaching. The students are required to collect as much materials as possible and propose improvement suggestion and innovative points to the selected technical materials according to the latest development trend of this course.

\section{Construction of Teaching Staffs}

Building high level teaching staffs is a key point in specialty construction planning, and it also involves promotion of teaching quality. In order to promote the students' practice abilities and innovative awareness, the teaching team must have the qualification of "double-teacher", i.e. the teachers are required to both be able to impart theoretical knowledge and guide the students to practice, both guide the students to conduct experiments and guide them to innovate in course design, contests and projects. This requires the teaching team to periodically discuss and form the mechanism of teaching content exchange. Let teachers of theoretical course enter the lab and get familiar with each experiment link. Meanwhile, let teachers of experimental course enter the classroom and master every theoretical knowledge point required by experiments. In addition, it also improves the structure of teaching staffs through multiple channels. Introducing high level, high education background and high title talents; 
inviting experts to give lectures or academic reports; and encouraging the teachers to study for higher degrees or study abroad. Along with the school pays more attention to construction of teaching staff, the teaching level is continuously improving, so favorable conditions are provided for PLC teaching reform and practice.

\section{Conclusion}

PLC teaching reform is an endless process, in the principle of "research as reforming and practicing", it focuses on forming constant perfection and innovation of PLC teaching reform and cultivation mode as well as focuses on survey and investigation, summarizing, reform, optimization and popularization. Following the guiding thought of "one basis, two cores", all-around teaching reform is carried out to "three modules" and teaching practice is carried out to grade 2011 and 2012 of agriculture electrification and automation, which substantively improved the PLC teaching level and cultivated inter-disciplinary engineering applied technical talents with sound theoretical basis, abundant practice abilities and strong innovative awareness in fields of agricultural electrification and automation.

\section{Acknowledgements}

The authors gratefully acknowledge the supported by the educational reform project of Sichuan Agricultural University (grant number: x2015025).

\section{References}

[1] Xie Yunmin,Liu Dehui, Exploration of teaching reform in PLC course [J], Journal of Nanchang Institute of Technology,2008,27(2):31-33.

[2] Zhu Yuejing, Exploration of teaching reform in PLC course [J], China Science and Technology Information, 2010,18:295-295.

[3] Li Xingbing, Teaching reform and practice in Electrical control and PLC course [J], The Chinese modern education equipment,2006,12:33-35.

[4] Wang Haiyue, research of teaching method in PLC Course [J], Journal Of Higher Education, 2016,9:106-107.

[5] Chen Zuo, The review of PLC's development trend [J], Electronics World,2016,1:85-87.

[6] Zhi Yan, Teaching reform and practice in Electrical control and PLC course [J], China power education, 2012,8:74-75,80.

[7] Zhou Jianping, Wang Zhiping, Improvement of "PLC Experimental Courese" [J], Research and Exploration in Laboratory,2012,31(10):119-121.

[8] Wu Huijun, Chen Jingyan, Project teaching reform in PLC course [J], HeiBei NongJi, 2015, 9: 49 $-50,52$.

[9] Xu Wen-na,WANG Chun,Tang Long,Liao Yinghua, Devepment of Fully Vitual PLC Experimental Teaching System [J] Research and Exploration in Laboratory, 2016, 35(3):92-95.

[10]Zhang Haobo, A Study on the Application of the "Task-driven" Teaching Approach in the Teaching of the Course of PLC [J], Journal of Chongqing Electric Power College,2015,3:5-6,17. 